\title{
A DISCRICIONARIEDADE ADMINISTRATIVA E O CONTROLE HERMENÊUTICO DA DECISÃO EM PROCESSOS ADMINISTRATIVOS: POR UM PROCESSO DECISÓRIO E UMA FILOSOFIA PROCESSUAL NO DIREITO ADMINISTRATIVO
}

\author{
THE ADMINISTRATIVE DISCRETION AND THE HERMENEUTICAL CONTROL OF \\ THE DECISION IN ADMINISTRATIVE PROCESSES: BY A DECISION-MAKING \\ PROCESS AND A PROCEDURAL PHILOSOPHY IN ADMINISTRATIVE LAW
}

Fernando Rodrigues Martins

Doutor e Mestre em Direito Civil pela PUC/SP; Vice-presidente do Instituto de Direito Privado; Professor de Direito da Universidade Federal de Uberlândia; Professor de pós-graduação da Universidade Federal de Uberlândia; Coordenador do Programa de Mestrado da Faculdade de Direito da UFU; Coordenador Pedagógico do Centro de Estudos e Aperfeiçoamento do MPMG; Promotor de Justiça em Minas Gerais.

E-mail: frodriguesmartins@icloud.com

Gustavo Nascimento Tavares

Mestrando em Direito pelo programa de pós-graduação em Direito da Universidade Federal e Uberlândia (UFU); Graduação em Matemática e Graduação em Direito pela Universidade Federal de Uberlândia (UFU)

E-mail: gustavosersan@gmail.com

Recebido em: 06/03/2017

Aprovado em: 11/01/2019

RESUMO: O presente artigo propõe, segundo a visão hermenêutica e processual do direito administrativo, discutir critérios decisórios no âmbito da Administração Pública e estabelecer limites interpretativos sob uma nova realidade, isto é, superando a discricionariedade e a legalidade como únicas balizas decisórias. Por meio do método indutivo, o trabalho visa erguer um juízo de probabilidade sobre a aplicação da hermenêutica e do processo na construção, e na fiscalização das decisões administrativas. Para tal, procurar-se-á demonstrar que no direito administrativo, as decisões são passíveis de verificação jurídica, tanto na esfera jurisdicional, quanto na esfera administrativa, porém, tal controle deve ser exercido sob novos parâmetros, que são: (i) a hermenêutica processual, que garanta democratização do direito e construção das decisões administrativas por meio de uma filosofia processual; e (ii) o processo hermenêutico de interpretação, que permite liberdade decisória revestido de padrões jurídicos, por meio de um circulo reflexivo interpretativo. Portanto, a decisão administrativa é passível de controle, todavia, pode e deve ser fiscalizada, tanto a partir de sua forma, por meio da hermenêutica processual, que contemple modos de construir a decisão, quanto a partir de seu conteúdo, por meio do processo hermenêutico reflexivo de interpretar e decidir conforme critérios pré estabelecidos.

Palavras-chave: Direito administrativo. Processo hermenêutico. Hermenêutica processual. Discricionariedade. Legalidade. 
ABSTRACT: This article proposes, according to the hermeneutic and procedural view of administrative law, to discuss decision-making criteria within the Public Administration and to establish interpretative limits under a new reality, that is, overcoming discretion and legality as the only decision-making framework. By means of the inductive method, the work aims to raise a judgment of probability on the application of hermeneutics and the process in the construction, and on the supervision of administrative decisions. To this end, it will be tried to demonstrate that in administrative law, decisions are subject to legal verification, both in the jurisdictional sphere and in the administrative sphere, but such control must be exercised under new parameters, which are: (i) Procedural hermeneutics, which guarantees democratization of the law and construction of administrative decisions through a procedural philosophy; And (ii) the hermeneutic process of interpretation, which allows for decision-making freedom with juridical standards, through an interpretive reflexive circle. Therefore, the administrative decision is subject to control, however, it can and should be supervised, both from its form, through procedural hermeneutics, which contemplates ways of constructing the decision, as well as from its content, through the process Hermeneutic to interpret and decide according to pre-established criteria.

Keywords: Administrative law. Hermeneutic process. Procedural hermeneutics. Discretionary. Legality.

SUMÁRIO: Introdução; 1 O rearranjo estrutural da legalidade e da discricionariedade diante dos novos paradigmas da administração pública: o papel da hermenêutica na unidade e reordenação do direito administrativo; 2 Uma visão hermenêutica da discricionariedade no direito administrativo: por um novo modelo de controle das decisões administrativas; 3 O processo como palco do controle hermenêutico das decisões administrativas: a superação do paradigma da discricionariedade e da legalidade para o paradigma processual da decisão no âmbito administrativo; 4 Apontamentos sobre decisões administrativas adequadas e inadequadas sob a ótica hermenêutica e processual no plano administrativo; Conclusão; Referências.

\section{INTRODUÇÃO}

Ainda que as decisões no âmbito do direito administrativo sejam dotadas de elementos políticos, não estão desvencilhadas dos elementos jurídicos. Nesse sentido, a legalidade e a discricionariedade mostraram-se insuficientes ao propósito de limitar a interpretação nesse ramo do direito. Ou seja, o constitucionalismo e a irradiação dos direitos fundamentais que transformaram o direito em um sistema abstrato de regras e princípios, permitiram um alargamento das possibilidades de interpretação, transferindo para a decisão o ponto de convergência do direito, inclusive o direito administrativo. Portanto, o estudo da decisão torna-se essencial para delinear os limites dessa capacidade interpretativa.

A hermenêutica processual e o processo hermenêutico de interpretação-decisão podem ser elementos de suplementar as incertezas e os dilemas do direito. Isto é, a nova realidade do direito administrativo está no resultado eficiente de sua finalidade, e na normatividade principiológica que promove um fluxo de irrigação e renovação dessa área jurídica. Por conseguinte, no direito administrativo, assim com em todo o direito, a interpretação é o resultado do processo de produção das normas a partir do texto, porém, requer controle. Logo, a visão hermenêutica do direito administrativo se propõe a criar limites adequados para as decisões do poder público, superando o paradigma da legalidade pelo paradigma hermenêutico da decisão. 
O presente trabalho pretende desconstruir a visão dogmática da discricionariedade e da legalidade administrativista para uma visão filosófica hermenêutica do que seja uma interpretação autêntica do direito. Para isso, torna-se imperativo apresentar o problema que se põe de como as decisões no direito administrativo podem ser controladas hermeneuticamente, juridicamente ou não, sem perder: sua autonomia, seu traço político, e se desviar de sua função deontológica de administrar o Estado, promovendo os direitos fundamentais.

A pesquisa se concentra-se, tanto na teoria própria do direito administrativo quanto na teoria do direito e na hermenêutica jurídica. Dessa maneira, o trabalho busca estabelecer um diálogo entre o direito administrativo contemporâneo e as teorias do direito que se debruçam sobre a interpretação no direito, voltado à disfunção das decisões no cenário administrativo. Nessa perspectiva, o tema delimita-se a rediscutir a discricionariedade e legalidade administrativa sob o viés da visão hermenêutica do direito.

Deste modo, buscar-se-á enfrentar os desafios interpretativos, que por um lado, aumentam a capacidade normativa do direito, mas, que por outro lado, podem ser um subterfúgio para arbitrariedades caso não dispuser critérios. $\mathrm{O}$ artigo visa demonstrar a hipótese de que: a decisão administrativa deve ser reconstruída sobre as bases hermenêuticas do direito e que, por meio do processo, pode ser controlada e fiscalizada democraticamente, sem perder sua tautologia constitucional.

O objetivo geral consiste em investigar formas de controle das decisões no âmbito do direito administrativo por meio da processualização dos atos decisórios e de balizas hermenêutica de controle da interpretação. Para lograr tal propósito, parte-se dos desígnios específicos, que são: (i) discutir os novos paradigmas do direito administrativo e apresentar uma visão hermenêutica desse ramo jurídico; (ii) demonstrar e justificar que a processualização da administração pública pode ser um elemento prévio de controle da decisão administrativa; e por fim, (iii) demonstrar que é essencial um controle hermenêutico nas decisões administrativas, e que o processo é o palco para a realização desse sistema de limites.

Para discutir os novos atributos da decisão no direito administrativo, o marco teórico será Habermas, em Direito e Democracia, utilizando-se do processo como meio de se democratizar o direito e evitar discricionariedade, Hans Georg Gadamer, em Verdade e Método, para dialogar a teoria do direito administrativo com a hermenêutica filosófica. Por outro lado, em relação ao direito administrativo, o marco teórico será a obra de Luiz Henrique Madalena e Lênio Luiz Streck, Discricionariedade Administrativa e Hermenêutica, para modelar as teorias gerais ao caso específico.

O direito encontra-se diante do desafio de encontrar limites para a interpretação sem que haja um retorno à modelos positivistas. Isto é, a abertura hermenêutica do direito deve ser um elemento de evolução, mas para tal, torna-se necessário criar mecanismos de se evitar corrupções sistêmicas. Nessa esteira, o Estado da arte encontra-se no estudo das decisões administrativas, das relações da hermenêutica com o direito e na importância de criar uma padrão decisório composto por elementos internos e externos.

A metodologia do trabalho será indutiva, partindo do juízo de probabilidade, o artigo pretende expor a nova realidade do direito administrativo com a refundação de algumas de suas bases dogmáticas, como por exemplo, a discricionariedade e a legalidade, para uma nova visão do direito administrativo a partir das teorias hermenêuticas do direito, ou seja, utilizando-se do vetor processual no direito administrativo, aplicar a ferramenta da hermenêutica nas decisões dessa área como forma de controle da interpretação.

A justificativa se dá pela importância de se buscar elementos que direcionem as decisões administrativas para o projeto de sociedade esculpido na Constituição, desse modo, a hermenêutica 
processual e o processo hermenêutico da decisão podem ser um fator que conformem tais decisões. O referencial teórico são obras sobre direito administrativo, teoria do direito e teorias da interpretação, tanto em autores internacionais quanto nacionais; específicos e gerais, e também, autores clássicos e contemporâneos.

\section{O REARRANJO ESTRUTURAL DA LEGALIDADE E DA DISCRICIONARIEDADE DIANTE DOS NOVOS PARADIGMAS DA ADMINISTRAÇÃO PÚBLICA: o papel da hermenêutica na unidade e reordenação do direito administrativo}

A origem do direito administrativo se confunde com a origem da legalidade e da discricionariedade. Pois, o direito administrativo origina-se ao final do período absolutista, e marca o desenho de uma nova ordem, em que o Estado era limitado, por meio das leis para garantir as liberdades individuais (MONTESQUIEU, 2000, p. 45), ou seja, era o início da separação de poderes para o exercício do poder público, no mesmo período, a discricionariedade administrativa surge como um alívio ao modelo legalista que permitia flexibilizar o rigor da lei para moldar o direito aos fatos. Portanto, o ramo "Direito Administrativo" e seus institutos bases, legalidade e discricionariedade, tem sua gênese no mesmo período histórico, de tal forma que a evolução da discricionariedade administrativa e da legalidade tornou-se a força motriz da evolução do direito administrativo.

Nesse sentido, para autores como Garcia de Enterría (2004, p.89-90), o tema central do direito administrativo é o controle da discricionariedade, todavia, tal controle perpassa pelo formato que a legalidade assume na função de arbitrar a mediação entre a discricionariedade e a fluidez interpretativa do direito administrativo (GASPARINI, 2012, p. 54-60). A relação entre o direito administrativo, legalidade e discricionariedade acompanham a própria evolução do direito, principalmente a influência que a hermenêutica e os direitos fundamentais promoveram nos núcleos da legalidade e da discricionariedade administrativa.

O surgimento do Estado decorre de uma necessidade de limitar o poder, de modo que, a Revolução Francesa de 1789 prometia a quebra do paradigma da autoridade, para o paradigma da legalidade estrita e positivista (ENTERRÍA, 1998, p. 27-30), com o objetivo de limitar e controlar o poder, contudo, a legalidade em seu início histórico se ocupou das relações individuais, garantindo os direitos liberais, mas, no que tange o controle do poder do Estado, a legalidade permitia a discricionariedade ampla do poder público (HOBBES, 2008, p. 111-113).

Nesse sentido, o pensamento liberal visava barrar o Estado de cometer abusos contra a sociedade, para tal, a legalidade era a ferramenta para garantir que o Estado soberano não interferisse na esfera privada dos cidadãos (LOCKE, 1994, p. 69-75). Porém, devido aos resquícios históricos e culturais do Estado Absolutista e a insuficiência da legalidade abarcar todas as situações possíveis que necessitavam de controle, a autoridade do Estado Liberal encontrou na discricionariedade um elemento de justificar seu poder de ação (NEVES, 2006, p. 50-52). Consequentemente, o propósito primordial da legalidade de ser o limite para o poder de decisão e ação do Estado, foi relativizado.

Posto esta moldura inicial, a discricionariedade continuou sendo um ponto frágil do direito administrativo diante da oscilação da força da legalidade como limite de poderes do Estado (GRAU, 2011, p. 210-214). Após a fase inicial do positivismo exegético do século XIX, a legalidade se mostrou insuficiente para ser o elemento que trouxesse limite ao direito, principalmente, nos países de tradição do Civil Law. Contudo, no positivismo normativo de Kelsen, tentou-se conciliar os poderes de interpretação à noção de legalidade jurídica (KELSEN, 1999, p. 
390), mas, mesmo no modelo kelseniano, a legalidade ainda era bastante relativizada pela discricionariedade, principalmente no direito administrativo.

Assim, a legalidade sempre esteve submetida à discricionariedade muito mais do que esta estivesse submetida àquela. Tal premissa é facilmente demonstrada pela própria evolução do direito administrativo, que começou primeiramente com forte traço de legalidade e um mínimo espaço para a discricionariedade, mas, que ao longo do século XIX e meados do século XX teve uma diminuição da legalidade e consequentemente um aumento de discricionariedade, sob o argumento de evolução do direito por meio da interpretação das normas (ENTERRÍA, 2000). Isto é, na ausência de lei sobre determinado assunto, prevalecia a interpretação do agente público, em um espiral hermenêutico que a interpretação do agente era um ato de vontade, ou seja, um ato discricionário (KELSEN, 1999, p. 385).

A grande virada ocorreu no pós-guerra (1945), isto é, na segunda metade do século XX o direito foi transformado. A normatividade da Constituição e a supremacia dos direitos fundamentais, alavancaram o direito administrativo para o status de direito administrativo constitucional (HESSE, 1991). Tais mudanças tiveram influência direta na reestruturação desse ramo jurídico, e também dos novos paradigmas que revolveram as bases da legalidade e da discricionariedade (DI PIETRO, 2012, p. 132).

Nessa perspectiva, sobre os novos fundamentos do direito administrativo, possuem relevância para o presente trabalho, os seguintes: (i) a constitucionalização do direito administrativo e a supremacia dos direitos fundamentais; (ii) a processualização do direito administrativo e consequente aumento da esfera de participação dos cidadãos nas tomadas de decisão, e por fỉm, (iii) a modernização do direito público com o aumento dos diálogos institucionais com outros ramos dos direito privado na busca por tonar este ramo do direito mais líquido e adaptável as transformações sociais.

Desse modo, tais itens convergem para um só elemento, tal elemento é a importância da hermenêutica no direito. Ou seja, a interpretação é o caminho para adequar o direito à realidade, de modo que a legalidade e a discricionariedade devem ser reformuladas para alcançarem a nova perspectiva da Administração Pública. Portanto, em cada paradigma é possível visualizar que houve um rearranjo das estruturas que são pilares para a unidade e a reordenação do direito como um todo e, em especial, o direito administrativo (CANARIS, 1989).

Em consequência disto, vê-se que, no Estado Democrático de Direito, o exercício do poder público deve ser sempre direcionado para a promoção dos direitos fundamentais. Isto é, o Estado deve ser o ator coadjuvante e a pessoa humana o ator principal, na interpretação do roteiro constitucional (MORAIS; SANTOS, 2015, p. 115). Contudo, o interesse público, que por muito tempo serviu de justificativa para conduzir a interpretação no direito administrativo, foi gradativamente se desviando da essencialidade desse objetivo, de forma que, o interesse público foi ramificado em primário e secundário (MELLO, 2006, p. 963), deste modo, os atores detentores da capacidade decisória do direito administrativo construíram um subterfúgio argumentativo para desviar a finalidade do Estado Democrático de Direito, criando um interesse público amplo, voltado para o interesse da coletividade, e um interesse público condensado, voltado para os interesses do próprio Estado (GASPARINI, 2012, p. 100-115).

Dito isto, a realidade que se apresenta no atual cenário é de que, no direito administrativista deve prevalecer a supremacia dos direitos fundamentais, isto é, a proporcionalidade no classificação do interesse público (BINENBOJM, 2008, p. 42-45), ou seja, a noção de direito sob o viés que o define como um sistema abstrato de regras e princípios (DWORKIN, 2002), tem reflexos na efetividade da Constituição, pois, por meio disto, o direito administrativo se vê obrigado a realizar e promover, com a máxima amplitude, os direitos 
fundamentais (SARMENTO, 2006). Portanto, o imperativo do direito administrativo é a efetividade dos direitos fundamentais, não podendo o interesse público ser mitigado ou relativizado fora dessa órbita hermenêutica. Logo, a consequência de tal conjuntura é que o direito administrativo se volta para a realização da Constituição (SARLET, 2010), isto é, o peso de valores democráticos e a normatividade dos princípios são molduras que limitam a discricionariedade para além da simples legalidade.

O Estado foi redefinido, de modo que, no Estado Liberal, a exigência era de não interferência nas liberdades individuais, já no Estado Democrático de Direito, a exigência é muito mais complexa, pois, o Estado tem deveres sob a forma de mandamentos e limites sob a forma de proibição (ALEXY, 2002, p. 450-452). Portanto, a constitucionalização do direito administrativo almeja promover este novo papel do Estado, de elevar os direitos fundamentais e a democracia como valores intangíveis.

Outro importante paradigma que modificou a estrutura do direito administrativo, foi a processualização dos atos administrativos. Ou seja, a decisão administrativa deixou de ser centralizada na autoridade do administrador público e passou a ser pautada por princípios processuais que dão legitimidade à decisão, tais princípios são: contraditório, proporcionalidade, razoabilidade, transparência, eficiência, dignidade da pessoa humana e outros. Deste modo, o procedimento é o elementos que democratiza o direito (LUHMANN, 1980), e nesse mesmo sentido, o processo expandi o diálogo e promove a integração sistêmica que inclui a participação da sociedade na tomada de decisões (HABERMAS, 2002, p. 153).

A relação do procedimentalismo com a interpretação está embasada na participação da sociedade, na necessidade de justificação dos atos preordenados e na fundamentação das decisões, ou seja, tais elementos garantem que a decisão e a interpretação tenham lastro jurídico (HABERMAS, 1997, p. 190). Portanto, o processo administrativo promove certo equilíbrio entre direito e democracia, pois, sopesa os dois valores.

A Lei n ${ }^{\circ} 9.784$ de 19991, Lei que regula os Processos no Âmbito da Administração Pública Federal, traz diversos elementos que direcionam a decisão administrativa para os limites do direito e também para os fundamentos democráticos que dão legitimidade a estas, os arts. 26, 27 e 282 definem critérios para que a decisão administrativa seja integrada ao interessados na decisão, por

\footnotetext{
${ }^{1}$ BRASIL. Lei no 9.784, 29 mar. 1999. Regula o processo administrativo no âmbito da Administração Pública Federal. Disponível em: <http://www.planalto.gov.br/ccivil_03/leis/L9784.htm> Acesso em 01 fev. 2017.

${ }^{2}$ Art. 26. O órgão competente perante o qual tramita o processo administrativo determinará a intimação do interessado para ciência de decisão ou a efetivação de diligências. § 10 A intimação deverá conter: I - identificação do intimado e nome do órgão ou entidade administrativa; II - finalidade da intimação; III - data, hora e local em que deve comparecer; IV - se o intimado deve comparecer pessoalmente, ou fazer-se representar; V - informação da continuidade do processo independentemente do seu comparecimento; VI - indicação dos fatos e fundamentos legais pertinentes. § 20 A intimação observará a antecedência mínima de três dias úteis quanto à data de comparecimento. $\S$ 3o A intimação pode ser efetuada por ciência no processo, por via postal com aviso de recebimento, por telegrama ou outro meio que assegure a certeza da ciência do interessado.§ 4o No caso de interessados indeterminados, desconhecidos ou com domicílio indefinido, a intimação deve ser efetuada por meio de publicação oficial.§ 5o As intimações serão nulas quando feitas sem observância das prescrições legais, mas o comparecimento do administrado supre sua falta ou irregularidade.

Art. 27. O desatendimento da intimação não importa o reconhecimento da verdade dos fatos, nem a renúncia a direito pelo administrado. Parágrafo único. No prosseguimento do processo, será garantido direito de ampla defesa ao interessado.

Art. 28. Devem ser objeto de intimação os atos do processo que resultem para o interessado em imposição de deveres, ônus, sanções ou restrição ao exercício de direitos e atividades e os atos de outra natureza, de seu interesse.
} 
meio da garantia do contraditório e da participação, já o art. 48 e 493 estabelecem o dever da Administração Pública oferecer uma resposta aos administrados, consolidando um dever do poder público de prestar contas, e no mesmo sentido, o art. 504 estabelece o imperativo de motivação das decisões administrativas, como forma de evitar abusos, enfim, a Lei 9.784/1999 constitui um importante elemento de democratizar a decisão administrativa e uma barreira para os excessos discricionários.

Ainda nessa acepção, em uma administração pública processualizada, conceitos rígidos como legalidade e discricionariedade perdem significativo espaço. A legalidade dá lugar à juridicidade, ou seja, o sistema jurídico é a base decisória, e não apenas a lei formal em sentido estrito (ROCHA, 2014). Por conseguinte, o processo torna-se um palco para a fluidez e realização dos direitos fundamentais, dando legitimidade ao direito, e retirando decisões arbitrárias do sistema (LUHMANN, 1980). A modernização e constitucionalização do direito administrativo dependem de sua processualização, pois somente por esta ferramenta, os dois outros paradigmas são realizados concretamente (SILVÉRIO JÚNIOR, 2012, p. 38).

Por conseguinte, outro fator que modificou a estrutura da Administração Pública reside na modernização desta. O Estado diminui de tamanho para ser mais eficiente (MIRAGEM, 2013, p. 30). Ou seja, a descentralização administrativa, a busca por eficiência e a escolha por exercer uma tarefa regulatória muito mais do que uma tarefa executória, deram nova roupagem à Administração Pública. A máxima de que aos cidadãos cabe o que não é proibido e, que à Administração Pública apenas cabe o que é permitido por lei, ainda é válida, mas, a rigidez dessa premissa passa por uma transformação, de modo que, as formas de controle que a Administração exerce e o controle a que esta se submete estão diretamente ligadas à unidade e ordenação do sistema jurídico, (CANARIS, 1989).

A Administração Pública caminha no sentido de uma atuação em rede, isto é, em uma hierarquia flexibilizada, que visa alcançar resultados, muito mais do que exercer um rígido controle procedimental (MARTINS, 2013). Portanto, o direito administrativo passa a reger relações de gestão, e não mais simples relações de poder. Logo, o Estado possui uma geometria variável e uma interdependência em diversos ramos de sua atuação, ou seja, o modelo de gestão pública, verticalmente, ganhou em profundidade técnica e especialidade decisória, e horizontalmente, ampliou suas fronteiras de ação por meio de um agir regulatório, que garanta resultados melhores.

Essa modernidade que alavancou a Administração Pública está diretamente ligada à diversas reformas que ocorreram no âmbito da administração pública no período de 1990 à 1999 , ou seja, diversas leis deram essa nova dimensão do poder público, dentre elas tem destaque, a

\footnotetext{
${ }^{3}$ Art. 48. A Administração tem o dever de explicitamente emitir decisão nos processos administrativos e sobre solicitações ou reclamações, em matéria de sua competência.

Art. 49. Concluída a instrução de processo administrativo, a Administração tem o prazo de até trinta dias para decidir, salvo prorrogação por igual período expressamente motivada.

${ }^{4}$ Art. 50. Os atos administrativos deverão ser motivados, com indicação dos fatos e dos fundamentos jurídicos, quando: I - neguem, limitem ou afetem direitos ou interesses; II - imponham ou agravem deveres, encargos ou sanções; III - decidam processos administrativos de concurso ou seleção pública; IV - dispensem ou declarem a inexigibilidade de processo licitatório; V - decidam recursos administrativos; VI - decorram de reexame de ofício; VII - deixem de aplicar jurisprudência firmada sobre a questão ou discrepem de pareceres, laudos, propostas e relatórios oficiais; VIII - importem anulação, revogação, suspensão ou convalidação de ato administrativo. § 1o A motivação deve ser explícita, clara e congruente, podendo consistir em declaração de concordância com fundamentos de anteriores pareceres, informações, decisões ou propostas, que, neste caso, serão parte integrante do ato. § 2o Na solução de vários assuntos da mesma natureza, pode ser utilizado meio mecânico que reproduza os fundamentos das decisões, desde que não prejudique direito ou garantia dos interessados. § 30 A motivação das decisões de órgãos colegiados e comissões ou de decisões orais constará da respectiva ata ou de termo escrito
} 
emenda constitucional $\mathrm{n}^{\mathrm{o}} 18$ de 1998, considerada uma micro reforma no direito administrativo, a lei de processo administrativo, a lei de improbidade, e outras leis que permitiram uma modernização do direito público regulatório (MARTINS, 2013).

Portanto, sob estes três pilares, que são: (i) constitucionalização; (ii) processualização e (iii) modernização gerencial; a Administração Pública possui elementos que renovaram a relação entre Estado e sociedade, posto isto, é maniqueísta a ideia de que a legalidade e a discricionariedade ainda permanecem inalteradas, presas ao modelo do Estado Liberal (FREITAS, 1999). Desta maneira, a expansão gerencial do Estado com sua diminuição estrutural, cria um Estado descentralizado e interdependente, isto é, amplia sua capacidade decisória aumentando também a participação popular, mas por outro lado, tal ampliação torna a legalidade insuficiente para limitar e controlar o poder público (MARTINS, 2013).

Diante do que foi exposto, os novos paradigmas da Administração Pública, convergem para uma ampliação da capacidade interpretativa dos atores que exercem o poder normativodecisório no âmbito do poder público. Isto é, a legalidade como único elemento que vincula as decisões administrativas é insuficiente, do mesmo modo, que a liberdade discricionária não contempla a justificativa para todas decisões possíveis. Nessa linha de pensamento, torna-se imperativo que haja no direito administrativo, uma hermenêutica processual que molde externamente a decisão administrativa e um processo hermenêutico que dê conteúdo jurídicodemocrático às decisões. Pois, dessa maneira, o controle administrativo e jurisdicional do poder público será adequado aos valores do Estado Democrático de Direito.

A hermenêutica é o vetor que possibilita romper os mitos de que a discricionariedade é uma forma de distorcer a legalidade, e que os atos vinculados estão estritamente presos à legalidade, pois, em ambas as situações são necessárias interpretação. Logo, uma hermenêutica administrativista pode ser o elemento que limite a interpretação e exerça o controle na tomada de decisões pelo poder público (MADALENA; STRECK, 2016, p. 207-208).

\section{UMA VISÃO HERMENÊUTICA DA DISCRICIONARIEDADE NO DIREITO ADMINISTRATIVO: por um novo modelo de controle das decisões administrativas}

A análise jurídica é fundamentalmente interpretativa. Conforme as ideias de Ronald Dworkin (2005, p. 176), o direito se assemelha a literatura diante da essencialidade da interpretação, isto é, a compreensão do direito se dá pela ótica do interprete, e este deve possuir elementos políticos e jurídicos para alcançar a melhor decisão. Nessa lógica, o pensamento de Dworkin em observar o direito com um sistema que ofereça respostas corretas e que transmita unidade e coerência, desloca a importância da interpretação no direito para o momento de aplicação do direito, ou seja, quem decide, primeiramente interpreta a partir de algum parâmetro.

Feita esta consideração introdutória, neste tópico pretende-se demonstrar que a discricionariedade não pode ser utilizada sob um véu de legalidade raso e sem profundidade jurídica. A virada linguística no direito possibilitou que fosse superado o paradigma da filosofia da consciência, para o paradigma de uma hermenêutica jurídica, transformadora e compatível com as possibilidades complexas do Estado Democrático de Direito (STRECK, 2014).

A discricionariedade, seja ela no âmbito jurídico ou administrativo, sempre deve ser questionada, principalmente no Estado Democrático de Direito, pois, nesse palco social, a gravidade constitucional exerce força constante no sentido de produzir um projeto de sociedade ideal (MORAIS; SANTOS, 2015, p. 112). Nesse sentido, a discricionariedade utilizada como 
produto da vontade do agente na ausência de norma, não é bem vinda em uma sociedade democrática (HABERMAS, 2003, p. 61-67).

Desse modo, na atual divisão dos poderes do Estado, a relação entre constitucionalismo e democracia, ora consegue equilibrá-los, ora causa distorções institucionais devido à imprecisão dos padrões criteriológicos políticos e jurídicos na atuação do poder administrativo e consequentemente na fisscalização exercida pelo Poder Judiciário. Isto é, a força contramajoritária do direito deve existir para permitir que a força política da democracia seja plena, porém, quando a discricionariedade é exercida desamarrada de princípios hermenêuticos constitucionais cria-se uma tensão perigosa entre tais valores, e as finalidades destes são desviadas do seu sentido deontológico constitucional (BARROSO, 1999).

No direito administrativo, essa tensão também existe, de modo que no Estado Democrático de Direito a administração pública também age sob a força contramajoritária do direito, mas por outro lado, também é impulsionada pelo peso democrático que sua atuação exige. Portanto, para que exista discricionariedade, esta deve atuar em um limite ínfimo, pois, a normatividade constitucional permite pouca abertura sistêmica para manipular o ordenamento, isto é visto principalmente pelo tamanho do projeto constitucional que se desenha em nossa Constituição de 1988. Ou seja, no Brasil a Constituição fez muitas promessas, como pode ser observado pela densidade que nossa carta de direito possui (NEVES, 2007).

Diante dessa conjuntura, o direito, em especial o direito administrativo, se vê vinculado à várias tarefas programáticas e, ainda que exista algum vácuo normativo, a força dos princípios constitucionais é responsável para resolver os dilemas, e não mais a vontade do agente. Isto é, a discricionariedade não é mais uma liberdade para agir quando não existe lei, pois ainda que não exista lei, existe um corpo principiológico constitucional que responde sob quais direções a interpretação, e consequentemente a ação do agente, deve ser seguida (LORENZETTI, 2009, p. 322-329).

Feito essa panorama geral, conclui-se que a discricionariedade é insuficiente para dirimir conflitos interpretativos. Em outras palavras, assim como a legalidade se tornou simplória no Estado Democrático de Direito e deu lugar a uma juridicidade ou normatividade constitucional, a discricionariedade também necessita de uma renovação conceitual para abarcar a hipercomplexidade das decisões, sejam elas administrativas ou jurídicas. Portanto, a liberdade política dos agentes da administração pública não pode ser generalizada para todas as formas decisão como uma autonomia ilimitada, sendo apenas controlada pelo rigor do Poder Judiciário (FERNANDES, 2013, p. 294 e p. 299).

A esfera administrativa também pode e deve controlar seus atos sob um viés jurídico constitucional, para isto, podendo se valer da hermenêutica filosófica, para interpretar conforme o ordenamento, desse modo, segundo Friedrich Muller, a interpretação deve atender o programa esculpido na norma, isto é, o agente deve a partir do texto, caminhar do texto para uma norma, feito isso deve proceder desta norma até a decisão, que se torna um produto diferente do texto e do programa da norma (MULLER, 2005).

No mesmo sentido, para o filósofo, Martin Heidegger (2008, p. 101), “o enunciado não reside na verdade, mas a verdade reside no enunciado, o que se dá pelo discurso". Ou seja, a interpretação é o desenvolvimento das possibilidades projetadas na compreensão, de modo que, aquela, acontece concomitantemente a esta, linguagem não se torna uma terceira coisa entre o sujeito e o objeto, mas sim, a linguagem deve ser vista como a totalidade e não como apenas instrumento (STRECK, 2014).

Diante dessas premissas teóricas, a hermenêutica é essencial pois, tudo se dá na linguagem e não por meio desta, isto é, a hermenêutica não é instrumento, é propriamente o processo de 
compreensão e interpretação. Sobre a discricionariedade, esta deve ser vista como uma visão do todo e também uma visão das partes, nunca vista sob apenas uma perspectiva (ISAIA; HOFMAM, 2012, p. 170). Portanto, a hermenêutica filosófica de Gadamer desconstrói o ideal da filosofia da vontade que estabelecia que o interprete decidia para depois fundamentar, premissa que sustenta a discricionariedade. $\mathrm{O}$ que Gadamer propôs foi que o interprete apenas decide após encontrar fundamentos fáticos para isso, dito de outro modo, somente após encontrar uma visão geral do que se busca decidir com fundamentos constitucionais, o interprete está apto a produzir uma respostadecisão (GADAMER, 1997, p. 636).

A Constituição deve permear a pré-compreensão do interprete para ser concretamente realizada e não ser apenas um subterfúgio ou álibi argumentativo (NEVES, 2007). Nessa esteira, seja o ato discricionário ou vinculado o poder público tem o dever de fornecer respostas adequadas para cada caso, levando em conta o circulo hermenêutico de produção da decisão e não apenas produzir justificativa para o que se quer decidir (ISAIA; HOFMAM, 2012, p. 168). Portanto, sobre este manto teórico, o controle a ser exercido é tanto na esfera administrativa quando na esfera jurisdicional, pois, não mais se utiliza apenas da legalidade para decidir o modo de agir da Administração Pública, mas sim, o conjunto de princípios constitucionais que determinam a précompreensão e a interpretação.

Vejamos o que diz Hans Georg Gadamer (1997) a respeito das ideias de Heidegger sobre o tema:

O que Heidegger diz aqui não é em primeiro lugar uma exigência à praxis da
compreensão, mas, antes, descreve a forma de realização da própria interpretação
compreensiva. A reflexão hermenêutica de Heidegger tem seu ponto alto no fato
de demonstrar que aqui esta prejaz um círculo, mas, antes, que este círculo tem um
sentido ontológico positivo. A descrição como tal será evidente para qualquer
intérprete que saiba o que faz. Toda interpretação correta tem que se proteger-se
contra a arbitrariedade da ocorrência de "felizes ideias" e contra a limitação dos
hábitos imperceptíveis do pensar, e orientar sua vista "as coisas elas mesmas" (que
para o filósofo são textos com sentido, que também tratam, por sua vez, de coisas).
Pois o que importa é manter a vista atenta à coisa, através de todos os desvios a
que se vê constantemente submetido o intérprete em virtude das ideias que lhe
ocorram. Quem quiser compreender um texto, realiza sempre um projetar. Tão logo
pareça um primeiro sentido, no texto o intérprete prelinea um sentido todo.
Naturalmente que o sentido somente se manifesta porque quem lê o texto lê a partir
de determinadas expectativas e na perspectiva de um sentido determinado. A
compreensão do que está posto no texto consiste precisamente na elaboração desse
projeto prévio, que, obviamente, tem que ir sendo constantemente revisado com
base no que se dá conforme se avança na penetração do sentido. (GADAMER,
1997, p. $401-402$ ).

Para Gadamer, a linguagem fornece a todos os significados do mundo, e desse modo a estrutura da linguagem possui primazia e exibe a verdadeira dimensão do real, daí a importância da interpretação, pois, a realidade é inseparável da interpretação (GADAMER, 2002, p. 339). Portanto, ao olhar para a discricionariedade como possibilidade interpretativa, não se pode chegar a uma liberdade de escolhas, pois o circulo hermenêutico conduz ao intérprete a descobrir uma resposta e não impor uma escolha (GADAMER, 2002).

Diante do que foi exposto nesse tópico, a discricionariedade deve possuir novas formas de controle, dessa maneira, no presente trabalho a solução para esta forma de controle se dá pela hermenêutica filosófica em duas frentes, uma hermenêutica processual que contemple o modo de construção do significante (forma) da decisão e um processo hermenêutico que contemple a construção do significado (conteúdo) desta. 
Portanto, o controle jurisdicional não deve se abster somente à estrita legalidade e a uma atuação no sentido de invalidar a decisão, isto é, a completude sistêmica exige uma resposta que promova a integração constitucional às decisões administrativas, e também em caso de ausência de normas, o desvio de finalidade na decisão pode ser elemento que justifique a revisão da decisão administrativa pelo Poder Judiciário (GRAU, 2011, p. 207-210).

Por outro lado, no que tange a própria fiscalização interno exercido pela Administração Pública, o processo administrativo também permite a possibilidade que o órgão da administração exerça uma moderação de suas decisões. Ou seja, no próprio processo administrativo, para garantir o contraditório e a ampla defesa, a Administração deve realizar o controle da decisão e não deve apenas se fixar aos limites pautados por normas regulamentadoras suplementares, pois, o Estado Democrático de Direito exige uma atuação ampla, com densidade constitucional, e para isso não pode apenas se ater aos regulamentos, ainda que de caráter técnicos (FREITAS, 1999).

Logo, o processo de formação e verificação das decisões administrativas não pode ser somente pautado pelo paradigma da legalidade, deixando a discricionariedade a margem da interpretação normativa-constitucional tanto no âmbito jurisdicional, quanto no âmbito administrativo (SILVÉRIO JÚNIOR, 2012, p. 36). Porém, tal interpretação é ditada por mecanismos hermenêuticos e processuais que a limitam, para não criar um excesso discricionário ou até mesmo arbitrário. Posto isto, conclui-se pela necessidade de um amplo controle hermenêutico em todas as esferas de decisão administrativa do poder público, e o locus para tal exercício é o processo, pois desta forma, tanto a força contramajoritária de proteção dos direitos fundamentais quanto as bases democráticas de participação ficam diametralmente equilibradas (HABERMAS, 1997, p. 330).

\section{O PROCESSO COMO PALCO DO CONTROLE HERMENÊUTICO DAS DECISÕES ADMINISTRATIVAS: a superação do paradigma da discricionariedade e da legalidade para o paradigma processual da decisão no âmbito administrativo}

Após a revolução linguística do direito, houve um redesenho das fontes desse sistema, de modo que, a decisão passou a conformas as demais normas em um produto concentrado, em todas as esferas de poder (Legislativo, Executivo e Judiciário). Diante dessa nova roupagem, a decisão ganhou importância, seja no plano jurídico ou administrativo, pois a legalidade ao possuir alto grau de abstração necessita de um filtro interpretativo que condense o texto em uma norma apta a produzir efeitos (LORENZETTI, 2009, p. 179).

No caso do direito administrativo, as mudanças que transformaram esse ramo jurídico permitem dizer que é possível realizar um controle hermenêutico das decisões administrativas por meio do processo, e dessa forma dar um caráter mais jurídico e constitucional à decisão administrativa. Portanto, a juridicidade das decisões administrativas atuam em consonância com os parâmetros de unidade e de ordenação que são exigidos de um sistema jurídico no Estado Democrático de Direito (CANARIS, 1989). Logo a proposta de um controle hermenêutico das decisões administrativas se torna perfeitamente construtível (MADALENA; STRECK, 2016, p. 209).

Inobstante ao controle hermenêutico, deve haver um lugar e um modo de se fazer a realização de tal controle. Nesse sentido, a decisão no paradigma contemporâneo extrapolou os limites estritos da legalidade e reduziu a imensa liberdade discricionária. Posto a premissa de que deve existir um controle, é importante encontrar o momento exato de realizá-lo, para revesti-lo de legitimidade. Desse modo, com a ampliação das esferas de decisão em âmbito administrativo, 
decorrente da descentralização da administração pública e da transformação do Estado autoritário para o Estado regulador, cria-se uma ambiente para que o processo administrativo que produz a decisão seja o palco para o controle da discricionariedade e da juridicidade pela via da hermenêutica (SILVA, 2004).

A discricionariedade olhada sob o viés da oportunidade e conveniência por vezes pode ser solipsista, contudo, se construída sob as balizas de um processo administrativo que garanta, principalmente: participação da sociedade, debate com os envolvidos, amplo contraditório e fundamentação política e jurídica, transformam uma decisão autoritária e aintidemocrática em decisão justa, equilibrada, democrática e constitucional. Ainda nesse feixe de pensamento, a finalidade e a amplitude da decisão administrativa são extremamente relevantes para sua validade e permanência, pois, na esfera administrativa, o interesse público sempre deve estar em foco (SILVA, 2008). Neste ponto torna-se necessário definir melhor os conceitos dos termos até aqui utilizados: "processo hermenêutico" e "hermenêutica processual", de maneira minuciosa.

Por processo hermenêutico entende-se: o encaixe dos fundamentos que irão fazer nascer a decisão a partir do que diz o texto interpretado, de modo que, o elo que liga os fundamentos de construção da decisão são decifrados pela Constituição, e por princípios que orbitam o ordenamento. $\mathrm{O}$ processo hermenêutico é o significante da decisão e, a parte que vai compor o conteúdo desta substancialmente (WARAT, 1995, p. 112). O adjetivo "hermenêutico" compõe o conceito pois determina um critério acima da mera legalidade e da discricionariedade, isto é, visa dar maior complexidade e verticalização ao controle exercído. Portanto, dentro do conjunto de projeções desenvolvidas na compreensão, o processo hermenêutico induz a melhor decisão.

Por outro lado, a hermenêutica processual é o processo em si, em sentido formal, isto é, o significado (WARAT, 1995). É por meio do processo hermenêutico que a decisão ganha legitimidade, ou seja, é a linha de montagem da decisão, nesse caso, o termo "hermenêutica" é usado como substantivo, pois, representa uma filosofia do processo, isto é, este deve ser o elemento que produz uma decisão. Portanto a hermenêutica processual transmite a ideia de que as condições que o sujeito interpreta são mais importantes do que os objetos de sua compreensão. Feito essas considerações, parte-se agora para a aplicação de tais conceitos na demonstração de que pode haver um controle hermenêutico das decisões administrativas e tal controle deve ser exercido no (por meio do) processo.

Primeiramente, a constitucionalização da administração pública limita tanto o processo hermenêutico de fundamentação da decisão, estabelecendo quais critérios devem ser satisfeitos para que o caminho decisional seja válido, quanto limita a hermenêutica processual que dita os parâmetros de composição do processo que produz uma decisão (SARMENTO, 2006). Ou seja, o processo é primordialmente um elemento que evita surpresas nas decisões proferidas, daí a necessidade de que o processo se torne presente em todos as esferas de decisão no poder público, sem que isso prejudique o dinamismo que a Administração Pública exige (MIRAGEM, 2013, p. 85-92).

O processo não pode mais ser visto de forma isolada da Constituição e do Estado Democrático de Direito, desta maneira, o direito processual admite um caráter ontológico da jurisdição, isto é, se a decisão é o produto da aplicação do direito, o processo é o projeto dessa decisão, para tanto uma visão hermenêutica de controle permite que todos os atores processuais na esfera administrativa tenham efetiva participação na interpretação dos fatos/direitos (SILVÉRIO JÚNIOR, 2012, p. 42-43).

O compartilhamento de poderes decisórios em diversas esferas administrativas pode ser um elemento que dê maior caráter democrático às decisões. As eferas administrativas podem ser mais técnicas e menos generalistas, produzindo um resultado processual mais adequado e 
individualizado de acordo com a necessidade de cada cidadão ou coletividade (MIRAGEM, 2013, p. 70-73).

Todavia, a virada hermenêutica no direito permite que a solução do caso concreto seja pensada a partir da situação fática e não apenas a partir da lei, ou seja, é impossível encontrar respostas sem que o fato processual seja evidentemente levado em consideração (STEIN, 1996). Daí a importância do controle hermenêutico no interior do processo, pois, quanto mais próximo aos fatos melhor se pode compreender a melhor solução. Posto isso, torna-se evidente que a mera ideia de discricionariedade administrativa no atual estágio de uma hermenêutica processual resta superada (MADALENA; STRECK, 2016, p. 210).

Por mais que o Poder Judiciário exerça o controle jurisdicional das decisões, o processo administrativo pode ser um filtro que apure e dê um refinamento à decisão administrativa. Nesse sentido o controle jurisdicional exerce um controle mais correcional (decisão apenas de cassação, que devolve o mérito) e menos reformador (decisão que reforma o mérito, produzindo uma norma concreta para o caso), dessa maneira, o Poder Judiciário pode inclusive devolver a mérito administrativo para o órgão julgador apontando os erros e determinando que seja proferida nova decisão. Nesses casos o Poder Judiciário atua com responsabilidade institucional e deferência ao Poder Executivo, interferindo minimamente em sua esfera de atuação, preservando a separação e independência dos poderes, preservando a Democracia (SILVA, 2004).

Portanto, a legalidade é fonte insuficiente para abarcar a hipercomplexidade de fatos e as possibilidades interpretativas da norma na pós-modernidade. Do mesmo modo que, a discricionariedade é justificativa minimalista perante a dimensão normativa que a constituição exerce em todos os ramos jurídicos. Logo, o processo administrativo é o fio condutor dos fatos, que por meio da participação polifacética da administração pública (corpo técnico, poder político, poder normativo) e também dos cidadãos, produz como resultado uma decisão satisfatória. Dessa forma, ainda que seja levada ao controle jurisdicional, o caminho processual percorrido já está no "DNA" da decisão, de forma que, o espaço para atuação do Poder Judiciário é bastante reduzido (HABERMAS, 1997, p. 299).

Diante do exposto, tem-se que uma decisão administrativa, construída dentro de uma hermenêutica processual de critérios pré-estabelecidos somado a um processo hermenêutico de composição das razões de decidir, torna a tarefa do Poder Judiciário, em eventual revisão da decisão, mais objetiva, visto que esta possui um lastro normativo-constitucional (GASPARINI, 2012). Em síntese, se a Constituição possui normatividade e o agente administrativo detém prerrogativa de realizar um processo hermenêutico por meio de uma hermenêutica processual, para a tomada de decisões, tem-se aí um limite para a sua interpretação (ENTERRÍA, 2004).

Assim, fica demonstrado o modo (controle hermenêutico) e o lugar (processo administrativo) de se construir a decisão administrativa adequada. Tal decisão é aquela construída democraticamente, direcionada pela máxima efetividade dos direito fundamentais e que as possibilidades de compreensão estejam além do véu da legalidade, assumindo uma feição sistêmica, daí a importância da hermenêutica como modo de controle (MADALENA; STRECK, 2016, p. 167). Por outro lado, o lugar de realização dessa decisão adequada é o processo, pois, diante do controle por meio da interpretação, a ordenação processual é o melhor palco para a realização do círculo hermenêutico (COUTURE, 1993). 


\section{APONTAMENTOS SOBRE DECISÕES ADMINISTRATIVAS ADEQUADAS E INADEQUADAS SOB A ÓTICA HERMENÊUTICA E PROCESSUAL NO PLANO ADMINISTRATIVO}

Diante da discussão argumentativa apresentada, objetiva-se justificar a proposta teórica com a análise de decisões tomadas em processos administrativos, levadas ao judiciário, ou não, e verificar os pressupostos e as consequências da proposta hermenêutica e processual em confronto com os pilares da legalidade e da discricionariedade, e determinar sua adequação ao inadequação perante o Estado Democrático de Direito. Portanto, serão analisadas as seguintes decisões: (i) decisão administrativa referente à processo de desapropriação na cidade do Rio de Janeiro; e (ii) Decisão do Conselho Administrativo de Defesa Econômica (CADE) sobre processo administrativo envolvendo a discricionariedade técnica.

Tais decisões serão brevemente apresentadas a partir da sua analise judicial, de modo que, as decisões que se conformam no padrão decisório hermenêutico e processual não são objetos de reformas pelo Poder Judiciário, mas sim de fiscalização. Todavia, as decisões que ficaram restritas apenas aos padrões da discricionariedade e legalidade foram objetos de grande discussão e causaram turbulência no ordenamento como um todo, levando o mérito administrativo para a esfera do Judiciário.

Primeiramente, será objeto de diagnóstico, decisão administrativa tomada pelo Poder Público do Estado do Rio de Janeiro em questão envolvendo desapropriação. Nos últimos anos a cidade do Rio de Janeiro foi sede de vários eventos de grandes proporções, posto isso, houve diversas políticas públicas voltadas para a facilitação e realização de tais eventos, contudo, tais políticas, que a princípio, eram exercidas sob um véu de promoção do interesse público, na verdade atuaram em prol de interesses particulares e causaram graves lesões à direitos fundamentais (OLIVEIRA; VASCONCELLOS, 2014).

Por questões metodológicas será discutido aspectos de uma única decisão em especial, a decisão que determinou a retirada de povos indígenas do antigo museu do índio na cidade do Rio de Janeiro em 2013 para realizações de obras para a Copa do Mundo de 2014, porém, são inúmeros casos de processos de desapropriação que subvertem a legalidade e a discricionariedade, divergindo do interesse público (OLIVEIRA; VASCONCELLOS, 2014). Todavia, existem também decisões administrativas que contemplem a visão hermenêutica e processual do direito administrativo. Portanto o objetivo é apresentar um exemplo prático de decisão administrativa inadequada sob os parâmetros de uma filosofia processual e uma leitura hermenêutica do direito.

Em breve síntese, foi proposta ação de imissão de posse pelo Governo Estadual do Rio de Janeiro, em que se pleiteava a retirada forçosa dos povos indígenas que habitavam um imóvel público. O local que na década de 80 era o museu do índio, e que, há alguns anos, após o abandono do poder público, se tonou um refúgio de diversas etnias indígenas que procuravam apoio na cidade do Rio de Janeiro, se tornou uma aldeia com participantes de várias etnias habitando o prédio, de forma temporária ou permanente. O prédio do museu ficava próximo ao Estádio Municipal Mário Filho, "o Maracanã", diante desta conjuntura, o local ficou amplamente conhecido como "Aldeia Maracanã" e, era um centro indígena localizado dentro de uma área urbana (BRASIL, TRF2 ${ }^{\mathrm{a}}$, 2014).

O processo administrativo que estabeleceu a retirada dos povos indígenas do local é totalmente desprovido de preceitos constitucionais de contraditório, paridade de armas, supremacia dos direitos fundamentais, participação popular, participação das instituições, dentre outros. Houve 
violações claras aos art. 26, 27. 28, 48 e 50 da Lei $n^{0} 9.784$ de 19995 que rege os processos administrativos no âmbito Federal e norteia as leis estaduais sobre o tema. A decisão foi tomada pautada por parâmetros de legalidade e discricionariedade sem respeito a preceitos hermenêuticos constitucionais e sem um devido processo com fundamentação e justificação dos atos do Poder Público (em todo o processo não foram reconhecidos os direitos plurinacionais dos índios, e estes foram tratados de maneira inadequada pelo Estado). Mesmo após a controvérsia chegar ao Poder Judiciário, a questão não foi estabilizada e continuou sem uma hermenêutica constitucional de verificação do real interesse público em questão, de modo que a controvérsia ainda permanece sem decisão.

Portanto, a ausência de um processo hermenêutico na motivação e justificação das decisões administrativas, somado à violação de garantias processuais de participação das partes na construção da decisão, por meio de uma hermenêutica processual, que legitime o produto final do processo, causaram imenso transtorno social, gerando vários protestos e comoção da sociedade civil que se organizou para defender direitos fundamentais violados pelo Estado que deveriam ser protegidos e garantidos por este.

Por outro lado, existe decisões administrativas que contemplam os preceitos expostos no escopo teórico do artigo e produzem de forma adequada a decisão. O Conselho Administrativo de Defesa Econômica (CADE), tem caráter de órgão técnico e suas decisões de acordo com a doutrina tem caráter híbrido, ou seja possui elementos de decisão judicial e de decisão administrativa (MIRAGEM, 2013, p. 180-182). O caráter judicial das decisões do CADE encontram-se essencialmente na fundamentação, motivação e necessidade de uma instrução prévia, por outro lado, o caráter administrativo repousa na possibilidade de revisão judicial, e a flexibilidade das formalidades processuais.

As decisões do CADE são tomadas mediante ampla instrução processual com participação de todos os interessados, inclusive órgãos públicos que fortalecem a juridicidade de tais decisões como o Ministério Público e a Advocacia Geral da União, ou seja, pode-se verificar uma hermenêutica processual de decidir respeitando diversos posicionamentos acompanhando de participação de diversos atores sociais e institucionais (CADE, 2007, p. 17).

Nem todas as decisões tomadas por órgãos reguladores e órgãos administrativos com capacidade decisória estão totalmente de acordo com a proposta teórica do artigo, porém, no CADE existem vários exemplos de decisões administrativas adequadas sob os parâmetros de uma filosofia processual e uma leitura hermenêutica do direito.

Ainda nesse sentido, o conteúdo das decisões adminisitrativas do CADE, cada vez mais, se aproximam de uma intersecção com as decisões tomadas pelo Poder Judiciário, tanto no aspecto de constitucionalidade da decisão, quanto no aspecto normativo, isto é, produzir norma para a solução de uma caso concreto (regulamentos e portarias), respeitados os limites da jurisdição. Logo, as decisões tomadas pelo $\mathrm{CADE}$, ainda que tenha caráter técnico, observam preceitos constitucionais. Nesse sentido, tais decisões contemplam um processo hermenêutico de construção da decisão com respeito institucional e deferência ao valores constitucionais (CADE, 2010, p. 10).

A decisão do CADE escolhida se refere ao processo administrativo $\mathrm{n}^{\mathbf{o}}$ 08012.000677/1999-706, que versa sobre a prática de cartel realizado por companhias aéreas no

${ }^{5}$ BRASIL. Lei $\mathrm{n}^{\text {o } 9.784,29}$ mar. 1999. Regula o processo administrativo no âmbito da Administração Pública Federal.
Disponível em: <http://www.planalto.gov.br/ccivil_03/leis/L9784.htm> Acesso em 20 fev. 2017.
${ }^{6}$ BRASIL. Conselho Administrativo de Defesa Econômica - CADE, 1999. Processo Administrativo $\mathrm{n}^{\mathrm{o}}$
08012.000677/1999-70.
em: 
ano de 1999. O processo foi instaurado em vinte e oito de março de 2000, ou seja, já na vigência da lei de Processo Administrativo (CADE, 2007, p. 76-78). Em setembro de 2004, após um diferido processo decisório, com participação de vários atores sociais e institucionais, o CADE proferiu decisão reconhecendo a prática lesiva à ordem econômica com multa para as companhias aéreas 7 . Após a decisão do $\mathrm{CADE}$, as requeridas ingressaram com diversas ações judiciais em face da decisão do CADE, porém as liminares para suspender os efeitos da decisão foram todas indeferidas, (CADE, 2007, p.78) devido a robustez de fundamentação e justificação da decisão tomada em processo administrativo. Diante disso, o CADE, por meio de sua procuradoria ajuizou ações executivas perante o Poder Judiciário cobrando o cumprimento da decisão administrativa.

No presente caso o decisão administrativa apresentou uma hermenêutica processual de contemplar a participação de diversos setores econômicos e agentes do Estado, como AGU e Ministério Público, além de permitir todos os meios de defesa às empresas envolvidas, isto é, houve uma marcha processual pautada por princípios e garantias constitucionais. Da mesma forma, a decisão protegeu valores constitucionais relativos à ordem econômica, garantido um processo hermenêutico de construção de uma decisão voltada à hermenêutica constitucional.

Portanto, tal decisão é modelo decisório sob o espeque hermenêutico e processual do direito administrativo. Isto é, a decisão foi construída com participação dos envolvidos e permeada de valores constitucionais, sem estar vinculada apenas a legalidade e a discricionariedade. Com isso, o acesso à justiça não foi retirada das empresas condenadas em esferas administrativas, porém, a trabalho do Poder Judiciário foi mais fiscalizador do que reformador, consequentemente, promovendo a segurança jurídica na atuação estatal.

Diante dos casos brevemente apresentados pode-se concluir que no direito brasileiro é possível a adoção de uma postura hermenêutica e processual no direito administrativo de forma que as decisões sejam produzidas na máxima conformidade com a ordem constitucional e com mínimo desrespeito aos direitos fundamentais, impulsionando o Estado para cada vez mais se tornar um Estado Providência, ou seja um Estado que tem em sua razão de exsitir o dever de prover à sociedade da máxima condição para o exercício de seus direitos (MIRAGEM, 2013, p. 248-252). A discricionariedade e a legalidade precisam acompanhar a evolução da sociedade e do próprio direito administrativo.

\section{CONCLUSÃO}

O escopo do presente artigo não foi classificar quais as decisões administrativas estão isentas ou adstritas à discricionariedade, ou mesmo, negar que legalidade é a base normativa do sistema jurídico brasileiro, mas sim, oferecer uma aplicação teórica de controle da decisão administrativa por meio da hermenêutica filosófica e demonstrar que o processo é o lugar para se realizar tal controle, visto que, o Estado Democrático de Direito deve primordialmente zelar pela democratização das tomadas de decisão, ainda que tais decisões sejam em consonância com o direito.

$<$ http://sei.cade.gov.br/sei/institucional/pesquisa/processo_pesquisar.php?acao_externa=protocolo_pesquisar\&aca o_origem_externa=protocolo_pesquisar\&id_orgao_acesso_externo=0 $>$ Acesso 19 fev de 2017.

${ }^{7}$ BRASIL. Conselho Administrativo de Defesa Econômica - CADE, 1999. Processo Administrativo $\mathrm{n}^{\mathrm{o}}$ 08012.000677/1999-70. Disponível em: $<$ http://sei.cade.gov.br/sei/institucional/pesquisa/processo_pesquisar.php?acao_externa=protocolo_pesquisar\&aca o_origem_externa=protocolo_pesquisar\&id_orgao_acesso_externo=0 $>$ Acesso 19 fev de 2017. 
Pois bem, após reestruturar os lugares epistemológicos da discricionariedade e da legalidade no Estado Democrático de Direito, o trabalho partiu da nova visão da Administração Pública e os novos paradigmas do direito administrativo para justificar a necessidade de se olhar este ramo jurídico a partir de um espeque da hermenêutica filosófica, pois dessa forma, o controle das decisões estaria mais próximo da realidade, isto é, os poderes de interpretação do direito estão cada vez mais amplos, mas, os mecanismos de controle ainda permanecem presos à modelos positivistas utilizados em sociedades que viviam sobre a égide do cânone liberal de Estado.

Contudo, a evolução jurídica modificou profundamente as estruturas e bases que vigoravam até meados do século XX. Portanto, o retorno da filosofia ao direito possibilitou que toda a estrutura política e jurídica dos estados modernos fossem pautadas por questões éticas, mas especificamente, os direitos humanos. Logo, tal fenômeno promoveu que a Constituição tivesse densidade normativa sobre os demais sistemas jurídicos, promovendo uma constitucionalização em todo o direito.

Da mesma forma, o processo também ganhou protagonismo na atual configuração do direito, pois este, tem a precípua função de realizar o direito dando legitimidade aos seus atos, sem ferir liberdades e garantias fundamentais. Sobretudo, a processualização no âmbito administrativo é elementos que reveste as decisões administrativas de participação popular, fundamentação, justificação e contraditório, isto é, evita decisões centralizadas e arbitrarias do poder público.

No mesmo sentido, a modernização da administração, por meio da diminuição do Estado, da flexibilização estrutural e abandono de uma hierarquia rígida para uma atuação em rede, descentralizada e com poderes interdependentes voltados aos resultados ontológicos do Estado, tornaram o direito administrativo um campo dinâmico, alterando seus processos, de uma rigorosidade procedimental para um procedimento democrático de promoção de resultados.

Diante dessa nova realidade, o presente artigo advoga para uma nova visão hermenêutica das decisões administrativas, onde a interpretação é voltada para todo o sistema constitucional e não apenas para a legalidade, dessa forma, preconiza por meios hermenêuticos de decisão que reduzam ao máximo à discricionariedade. Portanto, a partir da hermenêutica filosófica proposta por Hans Georg Gadamer, onde a linguagem não é mero instrumento, mas o lugar onde se realiza a interpretação, a proposta é promover um processo hermenêutico de composição da decisão.

Em relação ao lugar de se promover esse controle hermenêutico, o palco escolhido deve ser o processo, pois, é o ambiente que torna possível o equilíbrio entre constitucionalismo e democracia, visto que, preserva tantos os aspectos jurídicos (formalidades) quantos os aspectos democráticos (participação). Portanto, o controle das decisões em esferas administrativas deve ao máximo ser promovido por meio da hermenêutica processual que reveste a decisão de legitimidade.

Diante de todo o exposto, o controle hermenêutico da decisão na esfera administrativa é benéfico até mesmo para o controle judicial, pois, desta forma, a decisão se torna mais robusta de juridicidade e de participação dos diversos atores sociais. Desse modo o Poder Judiciário exerce menos interferência na esfera administrativa.

Enfim, não se trata de resolver o problema da interpretação, visto que no direito sempre será imprescindível interpretar, porém, busca-se um controle mais adequado para a realidade em consonância com a evolução do direito.

\section{REFERÊNCIAS}

ALEXY, Robert. 2002. Teoria de los Derechos Fundamentales. Madri: Centro de estudos políticos e constitucionales, 2002. 
BARROSO, Luís Roberto. Interpretação e Aplicação da Constituição. Fundamentos de uma dogmática constitucional transformadora. 3. ed. São Paulo: Saraiva, 1999.

BINENBOJM, Gustavo. Uma teoria do direito administrativo: direitos fundamentais, democracia e constitucionalização. 2. ed. Rio de Janeiro: Renovar, 2008.

BRASIL. Conselho Administrativo de Defesa Econômica - CADE, 1999. Processo Administrativo $n^{\circ}$ 08012.000677/1999-70. Disponível em:

$<$ http://sei.cade.gov.br/sei/institucional/pesquisa/processo_pesquisar.php?acao_externa=protocolo pesquisar\&acao_origem_externa=protocolo_pesquisar\&id_orgao_acesso_externo $=0>$ Acesso 19 fev de 2017.

BRASIL. Lei $n^{\circ}$ 9.784, 29 mar. 1999. Regula o processo administrativo no âmbito da Administração Pública Federal. Disponível em:

<http://www.planalto.gov.br/ccivil_03/leis/L9784.htm> Acesso em 01 fev. 2017.

BRASIL. Tribunal Regional Federal da 2a Região. Agravo Interno 2013.02.01.003338-7 -RJ Rio de Janeiro. Relator: Desembargador Federal Marcus Abraham. Pesquisa de Jurisprudência, Acórdãos, 25 de agosto de 2014. Acesso em: <http://www10.trf2.jus.br/consultas?movimento> Acesso em: 15 fev. 2017.

CONSELHO ADMINISTRATIVO DE DEFESA ECONÔMICA - CADE. Guia Prático do CADE: a defesa da concorrência no Brasil. $3^{\mathrm{a}}$ ed. Revista ampliada, CIEE: São Paulo, 2007.

CONSELHO ADMINISTRATIVO DE DEFESA ECONÔMICA - CADE. Secretaria de Direito Econômico, Ministério da Justiça. Defesa da Concorrência no Judiciário. $1^{\mathrm{a}}$ ed. Publicação oficial: Brasília - DF, 2010. Disponível em:

$<$ http://www.mpsp.mp.br/portal/page/portal/Cartilhas/defesa\%20da\%20concorr\%C3\%AAncia.pd f $>$ Acesso em 22 de fev. de 2017

CANARIS, Claus-Wilhelm. Pensamento sistemático e conceito de sistema na ciência do direito. Introdução e Tradução: Antônio Menezes Cordeiro. Lisboa: Fundação Calouste Gulbenkian, 1989.

COUTURE, Eduardo J. Interpretação das leis processuais $2^{a}$ Ed. Tradução Gilda Maciel Corrêa Meyer Russomano. Rio de Janeiro: Ed. Forense, 1993.

DI PIETRO, Maria Sylvia Zanella. Direito Administrativo. 25 Ed. São Paulo: Atlas, 2012

DWORKIN, Ronald. Levando os direitos a sério. Trad. Nelson Boeira $1^{\circ}$ Ed. São Paulo: Martins Fontes, 2002.

DWORKIN, Ronald. Uma Questão de Princípios. Tradução: Luís Carlos Borges. São Paulo: Martins Fontes, 2005. 
ENTERRÍA, Eduardo García de. La lucha contra las inmunidades del poder. 3a ed. Madrid: Civitas, 2004.

ENTERRÍA, Eduardo García de; FERNÁNDEZ, Tomás-Ramón. Curso de derecho Administrativo. 7a ed. Vol I. Madrid: Civitas, 2000.

ENTERRÍA, Eduardo García de. Revolución francesa e administración contemporánea. 5. ed. Madrid: Civitas, 1998.

FERNANDES, Francisco Luiz. Princípio da juridicidade: o supra princípio normativo no direito público. Revista de Direito Brasileira, Brasília - DF, ano 3; vol. 6: set-dez 2013 p. 291-300. Disponível em: <http://www.rdb.org.br/ojs/index.php/rdb/issue/view/9> Acesso em 19 fev. 2017.

FREITAS, Juarez. O controle dos atos administrativos e os princípios fundamentais. 2. ed. São Paulo: Malheiros, 1999.

GADAMER, Hans-Georg. Verdade e método. 3. ed. Tradução por Flávio Paulo Meurer. Petrópolis: Vozes, 1997.

GADAMER, Hans-Georg. Verdade e método II. 2. ed. Tradução por Enio Paulo Giachini. Petrópolis: Vozes, 2002.

GASPARINI, Diógenes. Direito Administrativo. 17 Ed. São Paulo: Saraiva, 2012.

GRAU, Eros Roberto. O direito posto e o direito pressuposto. 8. ed. São Paulo: Malheiros, 2011.

HABERMAS, Jurgen. A Era das transições; tradução e introdução Flávio Siebeneichler. Rio de Janeiro: Tempo Brasileiro, 2003.

HABERMAS, Jurgen. A inclusão do outro; tradução George Speber e Paulo Astor Soethe. São Paulo: Loylola, 2002.

HABERMAS, Jurgen. Direito e Democracia: entre facticidade e validade. v. 1 e 2 Rio de Janeiro: Tempo Brasileiro, 1997

HEIDEGGER, Martin. Ser e Tempo. 3. ed. Tradução por Márcia Sá Cavalcante Schuback. Petrópolis: Vozes, 2008.

HESSE, Konrad. A força normativa da Constituição. Tradução: Gilmar Ferreira Mendes. Porto Alegre: Sérgio Antonio Fabris, 1991.

HOBBES, Thomas. Leviatã. 3. ed. Tradução: Rosina D’Angina. São Paulo: Ícone, 2008.

ISAIA, Cristiano Becker e HOFFMAM, Fernando. A Jurisdição processual civil no Estado Democrático de Direito: verdades universais ou respostas corretas? Revista de Direito Brasileira, Brasília - DF, ano 2; vol. 3: jul-dez de 2012; p. 157-176. Disponível em:

$<$ http:/www.rdb.org.br/ojs/index.php/rdb/issue/view/7> Acesso em 17 fev. 2017. 
KELSEN, Hans. Teoria Pura do Direito 6. ed. São Paulo: Martins Fontes, 1999

LOCKE, John. Segundo Tratado sobre o Governo Civil e Outros Escritos: Ensaio sobre a Origem, os Limites e os Fins Verdadeiros do Governo Civil. Traduzido por Magda Lopes e Marisa Lobo da Costa. Petrópolis: Vozes, 1994.

LORENZETTI, Ricardo Luis. Teoria da decisão judicial: fundamentos de direito. Trad. Bruno Miragem. São Paulo: Revista dos Tribunais, 2009.

LUHMANN, Niklas. Legitimação pelo procedimento. Tradução de Maria Conceição. Brasília: UnB, 1980.

MADALENA, Luis Henrique; STRECK, Lênio Luiz. Discricionariedade Administrativa e Hermenêutica. São Paulo: Jus Podivm, 2016.

MARTINS, Fernando Rodrigues. Controle do patrimônio público; São Paulo: Revista dos Tribunais, 2013.

MELLO, Celso Antônio Bandeira de. Curso de Direito Administrativo. 8. ed. São Paulo: Malheiros, 2006.

MIRAGEM, Bruno. A nova Administração Pública e o direito administrativo. $2^{\mathrm{a}}$ Ed. São Paulo: Revista dos Tribunais, 2013.

MONTESQUIEU, Do Espírito das Leis. Traduzido por: Charles de Secondat, Baron de. São Paulo: Saraiva, 2000.

MORAIS, Fausto Santos; SANTOS, José Paulo Shneider. A teoria da Constituição como imaginário para a hermenêutica constitucional brasileira. Revista de Direito Brasileira, Brasília DF, ano 5; vol. 10: 2015 p. 107-124. Disponível em:

<http://www.rdb.org.br/ojs/index.php/rdb/issue/view/13> Acesso em 17 fev. 2017.

MÜLLER, Friedrich. Métodos de Trabalho de Direito Constitucional, $3^{\mathrm{a}}$ ed., Rio de Janeiro: Renovar, 2005.

NEVES, Marcelo. A constitucionalização simbólica. 2. ed. São Paulo: Martins Fontes, 2007.

NEVES, Marcelo. Entre Têmis e Leviatã: uma relação difícil. São Paulo: Martins Fontes, 2006.

OLIVEIRA, Larissa; VASCONCELLOS, Úrsula et al. Desapropriação para megaeventos no Rio de Janeiro: interesse público de quem? Revista de Direito Brasileira, Brasília - DF, ano 4; vol. 8: mai-ago 2014 p. 295-316. Disponível em:

<http://www.rdb.org.br/ojs/index.php/rdb/issue/view/11> Acesso em 08 fev. 2017.

SILVA, Ovídio A. Batista da. Jurisdição, direito material e processo. Rio de Janeiro: Forense, 2008 
SILVA, Ovídio A. Batista da. Processo e ideologia: o paradigma racionalista. Rio de Janeiro: Forense, 2004.

SILVÉRIO JÚNIOR, João Porto. O processo constitucional como espaço dialogal discursivo da democracia. Revista de Direito Brasileira, Brasília - DF, ano 2; vol. 2: 2012 p. 29-45. Disponível em: <http://www.rdb.org.br/ojs/index.php/rdb/issue/view/6> Acesso em 19 fev. 2017.

ROCHA, Carmem Lúcia Antunes. Princípios Constitucionais da Administração Pública. 2. ed. Belo Horizonte: Del Rey, 1994.

SARLET, Ingo Wolfgang. A Eficácia dos Direitos Fundamentais. Uma teoria geral dos direitos fundamentais na perspectiva constitucional. Porto Alegre: Livraria do Advogado, 2010.

SARMENTO, Daniel. Colisões entre direitos fundamentais e interesses públicos. In SARLET, Ingo Wolfgang (Coord.) Jurisdição e direitos fundamentais: anuário 2004/2005. Porto Alegre: Livraria do Advogado, 2006.

STRECK, Lênio Luiz. Jurisdição Constitucional e Decisão Jurídica. 4ª Ed. São Paulo Revista dos Tribunais 2014.

STEIN, Ernildo. Aproximação sobre hermenêutica. Porto Alegre, EDIPUCRS, 1996

WARAT, Luis Alberto. O Direito e sua linguagem. $2^{\mathrm{a}}$ Ed.. Porto Alegre: Ed. Sérgio Antônio Fabris, 1995. 